\title{
Strategi komunikasi pariwisata dinas pariwisata kabupaten Bima dalam meningkatkan minat wisatawan
}

\author{
Haykal Asghary ${ }^{\mathrm{a}, 1, *}$ \\ ${ }^{\text {a }}$ Side Channel Universitas Ahmad Dahlan \\ ${ }^{1}$ Haykal@comm.uad.ac.id*; \\ * corresponding author
}

\begin{tabular}{ll}
\hline & ABS TRA C T \\
& Makalah ini bertujuan untuk mendiskripsikan bagaimana strategi \\
Article history & komunikasi yang dilakukan oleh dinas pariwisata kabupaten Bima untuk \\
Received 30-06-2020 & meninhkatkan minat wisatawan. Penelitin dalam makalah ini \\
Revised 02-07-2020 & menggunakan penelitian kualitatif yang bertujuan untuk mendapatkan \\
Accepted 02-07-2020 & gambaran yang menyeluruh serta mendalam berdasarkan situasi wajar \\
& dari kasus yang diteliti. Dalam penelitian ini penulis mengambil kesi \\
keywords & sulan bahwa Dinas Pariwisata Kabupaten Bima telah melaksanakan \\
Strategi komunikasi dengan menggunakan unsur-unsur modern \\
Pariwisata
\end{tabular}

Minat Wisatawan

This is an open access article under the CC-BY-SA license.

\section{Introduction}

Pariwisata merupakan salah satu faktor pendapatan daerah. Di Indonesia terdapat berbagai destinasi wisata yang dikunjungi oleh wisatawan dalam negeri maupun wisatawan asing. Kabupaten Bima memiliki potensi wisata yang luar biasa, baik berupa wisata alam maupun budaya, berada pada banyak titik lokasi destinasi serta tersebar di seluruh wilayah, juga karena kualitas dan daya tariknya yang sangat unik dan beragam (Gamal, 2004).

Semua potensi wisata harus dimaksimalkan dengan baik, mulai dari promosi, pemasaran hingga akses transportasi yang baik dengan menggunakan komunikasi pariwisata. Tentu pemerintah Kabupaten Bima selalu berupaya mengembangkan dan meningkatkan sektor pariwisata disana, sehingga tidak kalah dengan yang ada di daerah lain di Indonesia (Azizah \& Adawia, 2018).

Dinas Pariwisata (DISPAR) Kabupaten Bima tentu harus sudah siap menyiapkan strategi-strategi komunikasi pariwisata yang baik. Hal itu dilakukakan untuk segera meningkatkan minat wisatawan untuk datang ke kabupaten Bima dan dapat bersaing dengan pariwisata-pariwisata di daerah lain. Berdasarkan uraian latar belakang tersebut, peneliti tertarik melakukan penelitian tentang "Strategi Komunikasi Pariwisata Dinas Pariwisata Kabupaten Bima dalam Meningkatkan Minat Wisatawan (Suharyat, 2009)."

\section{Theorotocal Framework}

\subsection{Pengertian Komunikasi}

Laswell dalam buku Ilmu komunikasi teori dan praktik mengatakan Komunikasi adalah proses penyampaian pesan oleh komunikator kepada komunikan melalui media yang menimbulkan efek tertentu (Mulyana, 2007). 


\subsection{Strategi Komunikasi}

Strategi komunikasi merupakan paduan dari perencanaan komunikasi dan manajemen komunikasi untuk mecapai suatu tujuan (Sumarwan et al., 2008).

\subsection{Pariwisata}

Pariwisata adalah kegiatan dinamis yang melibatkan banyak manusia serta menghidupkan berbagi bidang usaha (Pendit, 2002). Pariwisata adalah suatu perjalanan yang dilakukan untuk rekreasi atau liburan dan juga persiapan yang dilakukan untuk aktivitas ini. Kajian komunikasi pariwisata memliki kedekatan biologis dengan kajian-kajian komunikasi dan pariwisata yang melahirkannya. Komunikasi menyumbangkan teori-teori komunikasi persuasive, teori komunkasi massa, teori komunikasi interpersonal dan kelompok. Sementara pariwisata sendiri menyumbangkan field kajian pemasaran pariwisata, destinasi pariwisata, aksesibilitas ke destinasi dan SDM serta kelembagaan Pariwisata. Dari ilmu-ilmu itulah yang akan menjadi dasar dalam perencanaan dan perancangan strategi-strategi Komunikasi Pariwisata. Dalam Pariwisata modern terdapat beberapa komponen penting, antara lain pemasaran, destinasi, aksesibilitas, SDM dan Kelembagaan Pariwisata (Sefira Ryalita Primadany, Mardiyono, 2013).

\section{Method}

Penelitian ini menggunakan penelitian kualitatif yang bertujuan untuk mendapatkan gambaran yang menyeluruh serta mendalam berdasarkan situasi wajar dari kasus yang diteliti. Metode penelitian yang penulis gunakan adalah metode deskriptif kualitatif. Sasaran penelitian ini adalah Dinas pariwisata Kabupaten Bima dan wisatawan yang berkunjung. Lokasi penelitan yaitu bertempat di beberapa kawasan di Kabupaten Bima yang mempunyai tempat wisata yang sering dikunjungi wisatawan. Penelitian kebanyakan akan dilakukan di setiap hari libur. Pada penelitian kualitatif, pengumpulan data dilakukan pada natural setting dan teknik pengumpulan data lebih banyak pada observasi berperan serta, wawancara mendalam, dan dokumentasi. Sugiyono (2010:63). Analisis data yang penulis dapatkan dimulai dengan menelaah seluruh data yang tersedia dari berbagai sumber, yaitu hasil wawancara, pengamatan yang dicatatkan dalam catatan lapangan, dokumen pribadi, dokumen resmi, foto dan sebagainya (Nathan \& Scobell, 2012).

Teknik Validasi Data (Uji Validitas) Berikut yang dilakukan peneliti untuk memeriksa keabsahan data : (1) Bandingkan hasil wawancara, data, dan hasil pengamatan. (2) Satukan hasil wawancara, data, dan hasil pengamatan. (3) Menggabungkan seluruh data yang diperoleh.

\section{Results and Discussion}

1) Komunikasi Pariwisata Dinas Pariwisata Kabupaten Bima

Strategi-staregi komunikasi pariwisata sudah disusun peneliti dalam kerangka teori sebelumnya. Yang sesuai dengan perencanaan strategi yang dilaksanakan oleh Dinas Pariwisata kabupaten Bima.

\section{2) Pemasaran}

Media merupakan alat untuk memasarkan pariwisata yang efektif, terlebih media online di era digitalisasi ini telah banyak berkontribusi dalam penyebaran informasi kepariwisataan secara luas. Selain kerja sama dengan media-media, Dinas Pariwisata kabupaten Bima dalam memasarkan dan mempromosikan destinasi-destinasi yang ada di Bima, juga melaksanakan event tahunan, serta promosi ke luar daerah dengan mengikuti event-event, pameran, festival keraton, dan lain sebagainya. Pemasaran menggunakan media-media diatas dianggap cukup efektif sementara oleh pihak Dinas Pariwisata. Oleh karena itu pemanfaatan media dan sistem informasi terus dipelihara agar wisatawan mudah mengakses informasi. 


\section{a) Destinasi}

Di kabupaten Bima sendiri banyak destinasi yang memliki daya tarik, baik itu pegunungan, pantai, maupun wisata buatan. Dari ketiga aspek penting dalam keunggulan pariwisata tersebut, ketiga-tiganya ada didalam pariwisata Bima. Itu yang menjadi alasan bahwa di Bima, potensi dan keunggulan pariwisata sangat lah bagus. Ditambah lagi kabupaten Bima berada di posisi strategis antara dua tempat wisata yang mendunia, yaitu pulau Bali dan Pulau Komodo. Untuk sarana dan prasarana pun sudah tersedia disebagian besar tempat wisata demi memenuhi kebutuhan dan kenyamanan wisatawan yang berkunjung. Sudah banyak fasiltas sarana dan pra sarana yang disediakan oleh DISPAR kabupaten Bima untuk wisatawan. Aksesibilitas Kemudahan daya jangkau menuju obyek dan daya tarik wisata sangatlah penting dalam pariwisata. Dengan kemudahan akses maka wisatawan akan merasakan kelancaran dan kenyamanan dalam perjalanannya. Akses jalan, Map, serta pemandu wisata sudah ada diseluruh tempat wisata.

Pengamatan dari peneliti sendiri, bahwa aksesibilitas menuju tempat wisata di kabupaten Bima bisa dikatakan belum merata sepenuhnya. Untuk sementara hanya di destinasi unggulan saja yang aksesisibilitas nya bagus dan mudah untuk perjalanan wisatawan. Meski demikian dari DISPAR kabupaten Bima sendiri secara berkala membangun aksesisibilitas yang merata dan menyeluruh. Untuk mewujudkan aksesibiltas yang baik tersebut, DISPAR Kabupaten Bima telah menyusun strategi perencanaan pengembangan aksesibilitas untuk meningkatkan pariwisata Kabupaten Bima khususnya lagi meningkatkan minat wisatawan untuk berkunjung ke Bima.

\section{b) Sumber Daya Manusia}

Hasil pengamatan dari peneliti sendiri, hampir seluruh kawasan wisata di kabupaten Bima SDM nya sangat aktif dalam meningkatkan pariwisata daerah. Dari pecinta alam yang sering melakukan kegiatan positif hingga masyarakat desa yang menampilkan atraksi budaya ditempat mereka masing-masing. SDM yang bagus dikabupaten Bima memudahkan pemerintah (DISPAR) dalam perencanaan pengembangan pariwisata terkait dengan sumber daya manusia (SDM).

\section{c) Kelembagaan Pariwisata}

Peneliti sendiri melihat, kelembagaan pariwisata sudah ada beberapa di kabupaten Bima, akan tetapi peran dari masing-masing lembaga tersebut masih kurang maksimal dan harus ditingkatkan lagi. Dengan terbentuk nya Kelembagaan Pariwisata seperti Persatuan Hotel dan Restoran Indonesia (PHRI), Association of the Indonesia Tours and Travel (ASITA), dan Himpunan Pramuwisata Indonesia (HPI). Diharapkan pemerintah perlu mendorong pemerhati pariwisata, industri pariwisata, dan pelaku pariwisata untuk sama-sama membangun Pariwisata agar menjadi wadah pemersatu sehingga dapat melaksanakan peranannya dalam pembangunan pariwisata secara unggul dan professional.

\section{3) Analisis Data}

Berdasarkam penelitian yang telah dilakukan peneliti melalui observasi. Wawancara dan dokumentasi, oleh karena itu pada tahap ini peneliti akan mebahas dan menganalisa data dengan teori yang telah disusun dalam kerangka pemikiran sebagai berikut :

\section{a) Pemasaran}

Dari pemasaran yang dilakukan oleh DISPAR, promosi-promosi lewat berbagai macam media, bisa dibilang cukup efektif, promosi event-event pariwisata dikabupaten Bima lewat mediamedia sosial, sangat efektif, berdasarkan hasil wawancara kepada masyarakat ataupun wisatawan, mereka mengikuti kegiatan pariwisata tersebut dari media sosial. Sedangkan lewat media cetak, seperti pamflet, brosur, serta baliho yang dibuat, ada beberapa masyarakat yang mengetahuinya, ada pula sebagian yang tidak mengetahui promosi dari media cetak tersebut.

\section{b) Destinasi}

Dari hasil data wawancara dan hasil pengamatan peneliti sendiri, di Kabupaten Bima memiliki semua unsur-unsur penting dalam pariwisata. Baik wisata alam, daya tarik wisata khusus, sampai daya tarik budaya. Wisatawan yang datang pun mengakui di kabupaten Bima sendiri mempunyai keindahan seperti daerah-daerah lain yang destinasinya sering dikunjungi oleh wisatawan lokal maupun asing. 


\section{c) Aksesibiltas}

Peneliti sendiri melihat untuk aksesibiltas pariwisata di kabupaten Bima belum merata seutuhnya. Dari apa yang disampaikan oleh pihak DISPAR, wisatawan, pengelola atau warga lokal, destinasi-destinasi yang ada di kabupaten Bima aksesibilitas nya masih belum sempurna, masih perlu disentuh dengan baik oleh kalangan-kalangan yang berhubungan dengan pariwisata. Untuk jalan pun peneliti melihat memang ditiap kawasan hanya didestinasi unggulan saja yang akses jalannya lancar digunakan wisatawan.

\section{d) Sumber Daya Manusia}

Peneliti sendiri melihat berdasarkan dari wawancara dari pihak DISPAR, wisatawan, dan pengelola atau warga lokal, serta pengamatan sendiri, memang pengembangan SDM di kabupaten Bima bisa dikatakan meningkat dari tahun-tahun sebelumnya. Aktif nya masyarakat didalam kegiatan pariwisata sangat membantu pemerintah dalam mengembangkan pariwisata di kabupaten Bima,

e) Kelembagaan Pariwisata

Dari hasil pemgamatan peneliti sendiri, untuk kelembagaan pariwisata yang ada dikabupaten Bima, memang sudah ada seperti yang sudah dijelaskan sebelumnya, kelompokkelompok ditiap destinasi juga sudah dibentuk. Pengelola atau warga lokal ditiap destinasi dari pengamatan peneliti sudah melaksanakan tugas dan fungsinya masing-masing, akan tetapi perencanaan dan pengelolaan destinasi wisata ditempat masing-masing harus dikembangkan dan ditingkatkan lagi.

\section{Conclusion}

Berdasarkan hasil penelitian dari hasil pengumpulan data, wawancara, observasi, dan dokumentasi peneliti, maka didapatkan kesimpulan sebagai berikut : Dinas Pariwisata Kabupaten Bima telah melaksanakan strategi komunikasi dengan menggunakan unsur-unsur modern komunikasi pariwisata untuk meningkatkan minat wisatawan, akan tetapi hasil nya belum merata, karena perlu memaksimalkan sleuruh unsur-unsur komunikasi pariwisata tersebut ke seluruh destinasi.

\section{References}

Azizah, A., \& Adawia, P. R. (2018). strategi pemasaran. Cakrawala - Jurnal Humaniora. https://doi.org/10.31294/JC.V18I2.4117

Gamal, S. (2004). Dasar-dasar Pariwisata. Yogyakarta: Andi, 2004. https://doi.org/10.15294/jejak.v7i1.3596

Mulyana, D. (2007). Ilmu Komunikasi: Suatu Pengantar. In Edisi Revisi.

Nathan, A. J., \& Scobell, A. (2012). How China sees America. Foreign Affairs, Vol. 91, pp. 37-54. https://doi.org/10.1017/CBO9781107415324.004

Pendit, N. S. (2002). Ilmu Pariwisata. Pariwisata.

Sefira Ryalita Primadany, Mardiyono, R. (2013). Analisis Strategi Pengembangan Pariwisata Daerah. Administrasi Publik.

Suharyat, Y. (2009). Hubungan Antara Sikap, Minat dan Perilaku. Komunikasi Massa Dan Efek Media Terhadap Individu.

Sumarwan, U., Djunaidi, A., Aviliani, Singgih, H. C. R., Sayono, J. A., Budidarmo, R. R., \& Rambe, S. (2008). Pemasaran Strategi. In Andi Office. 